\title{
Contribution of the guassa community eco-lodge to the conservation of wild mammals, birds and woody plants in menz-gera midir district, north shewa administrative zone, Ethiopia
}

\begin{abstract}
In recent decades, several eco-lodges have been established in biodiversity areas of Ethiopia, but quantitative scientific information that helps guide the sustainable management of eco-lodges is lacking. This study was the first attempt that examined the role of the GCEL for the conservation of wild mammals, birds, and woody plants. The objective of the study was to characterize and quantify species diversities and densities of wild mammals, birds, and woody plants in the compound of the eco-lodge and in the adjacent field. Following a total of six randomly aligned transects, field data on the species richness and abundance of wild mammals and birds across the landscape were collected in the compound of the GCEL (here after the EHH) versus in the adjacent field (here after the FGH)

Moreover, a systematic sampling design was employed to lay a total of 39 circular plots (i.e, each with a radius of $10 \mathrm{~m}$ ) and collect data on the species richness and abundance of woody plants. The results revealed that species richness, diversity, and evenness of wild mammals were 11, 1.6 and 0.67 , respectively, in the EHH and $11,1.4$ and 0.6 , respectively, in the FGH. Similarly, species richness, diversity and evenness of birds were 33, 3.3 and 0.96, respectively, in the EHH, and 29, 3 and 0.88, respectively, in the FGH. The woody species were represented by $16,2.7$ and 0.97 species richness, diversity, and evenness, respectively, in the EHH, and 16, 2.6 and 0.94 species richness, diversity, and evenness, respectively, in the FGH. The total mean densities of wild mammals recorded in the EHH and FGH were 16.0 and 7.5 individuals, respectively. Similarly, the total mean densities of birds computed in the EHH and FGH were 668.5 and 158.3 individuals, respectively. Moreover, the total mean densities of woody species estimated in the EHH and FGH were 37,665.2 and $16,845.6$ individuals, respectively. The findings of this study generated quantitative scientific information for policy-makers and planners that guides them toward better and more informed decision-making for eco-lodge establishment and management that is geared toward biodiversity conservation.
\end{abstract}

Volume 2 Issue 4 - 2017

\author{
Solomon Ayele Tadesse,' Demel Teketay² \\ 'Department of Natural Resources Management, Debre Berhan \\ University, Ethiopia \\ 2Department of Crop Science and Production, Botswana \\ University of Agriculture and Natural Resources, Botswana
}

\begin{abstract}
Correspondence: Solomon Ayele Tadesse, Department of Natural Resources Management, College of Agriculture and Natural Resource Sciences, Debre Berhan University, PO Box 445, Debre Berhan, Ethiopia, Tel +25 I I I I-68 I 5440, +25 I-946703660, Fax +25I-III-68I2065 Email solomon.ayele1972@gmail.com
\end{abstract}

Received: October II, 2017 | Published: November 08, 2017

Keywords: densities, eco lodge, guassa, species diversities

Abbreviations: EHH, erica heather habitat; FGH, festuca grassland habitat; GCCA, guassa community conservation area; GCEL, guassa community eco lodge; GGR, guassa grassland reserve

\section{Introduction}

In recent decades, several eco-lodges have been established in biodiversity areas of Ethiopia. For example, plenty of eco-lodges are found in Amhara, Oromia and Southern Nation, Nationalities and People's National Regional States. Most of the times, as ecolodges are established from environmentally friendly, economically feasible and socially acceptable local materials, we argue that ecolodges contribute much to the conservation of the local biodiversity. As biodiversity is one of the topmost attractions to tourists, ecolodges conserve the local biodiversity from human and livestock induced disturbances. For example, when natural plants existing in the compounds of eco-lodges are protected from illegal human and livestock induced encroachments, they attract plenty of wild mammal and bird species from the adjacent open fields. This is because they provide the incoming wild mammal and bird species with quality food, ${ }^{1,2}$ suitable cover from environmental extremes, ${ }^{3}$ breeding sites ${ }^{4}$ and concealment from risk of predation. ${ }^{5}$ Therefore, to maintain the long term survival of our natural ecosystems, eco-lodges play a central role in local biodiversity conservation in Figure 1. Despite the tremendous contributions of eco-lodges to local biodiversity conservation, there is a lack of scientifically tested quantitative information that addresses this issue in Ethiopia. In an attempt to bridge the gap of scientific knowledge, this study focused on assessing the role of the GCEL in the conservation of wild mammals, birds and woody plants in MenzGera Midir District, North Shewa Administrative Zone, Ethiopia. The reason why this site was selected as area of the study is that no study was done so far on the role of eco-lodge in biodiversity conservation.

The objective of the study was, therefore, to determine the diversity (species richness, diversity and evenness) and densities of wild mammals, birds, and woody plants in the compound of the GCEL (here after the EHH) and the adjacent field (here after the FGH). The following research question was addressed: are there 
significant differences in the species diversities and densities of wild mammals, birds, and woody plants in the EHH and the FGH? We hypothesized that species diversities and densities of wild mammals, birds, and woody plants in the EHH will be higher than in the FGH.

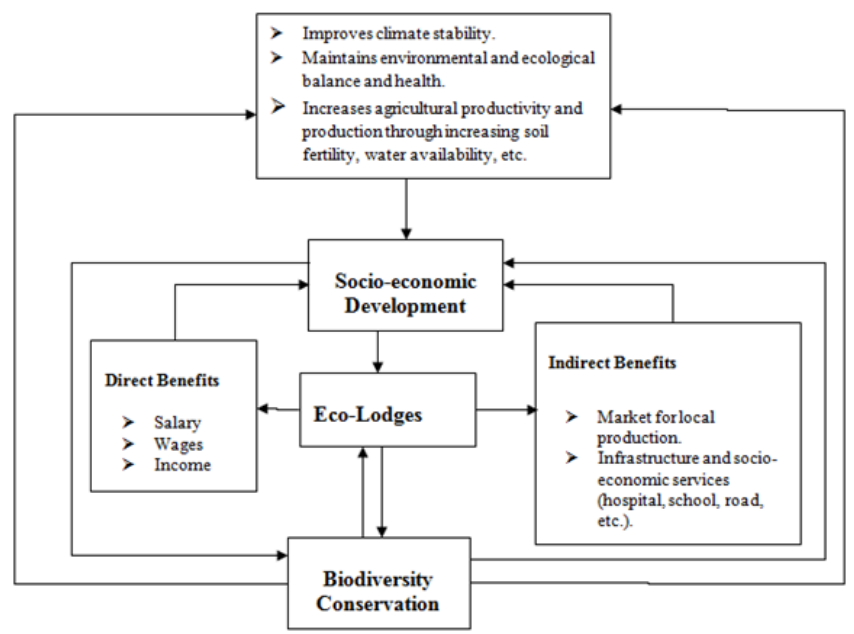

Figure I Conceptual framework illustrating the linkage of eco-lodges with biodiversity conservation and socio-economic development.

\section{Materials and methods}

\section{Study area}

The study was carried out in GCEL. GCEL is found in the GGR, also known as the GCCA. The GGR lies between $10^{\circ} 15^{\prime}$ $10^{\circ} 27^{\prime} \mathrm{N}$ and $39^{\circ} 45^{\prime}-39^{\circ} 49^{\prime} \mathrm{E}$ (Figure 2). The annual rainfall for the area averages between 1,200 and $1,600 \mathrm{~mm}$. The area ranges in altitude from 3,200 to $3,700 \mathrm{~m}$. The area is part of the Menz-Gera Midir District in North Shewa Administrative Zone, Ethiopia. ${ }^{6}$ The GGR covers an area of $98 \mathrm{~km}^{2}$, and it is one of the oldest known common property resource management in Sub-Saharan Africa. It has been the focus of an indigenous natural resource management institution, known as "Qero," system for over 400 years. ${ }^{7}$ The area is home to numerous endemic wild mammal species, including the iconic Ethiopian wolf, gelada and Ethiopian highland hare. ${ }^{8}$ Other wild mammal species living in the area include klipspringer, jackal, leopard, spotted hyena, African civets and serval cat. In addition, the endemic bird species that are found in the area include Ankober serin (Serinus ankoberensis), abyssinian catbird (Parophasma galinieri), abyssinian long-claw (Macronyx flavicollis), Ethiopian siskin (Serinus nigriceps), spot-breasted lapwing (Vanellus melanocephalus), and wattled ibis (Bostrychia carunculata). The reserve also supports important and endemic plant species including Guassa grass, giant lobelia, erica moorlands and species of Helichrysum and Alchemilla. Other common plant species that are found in the area include Carex monostachya A Rich, Carex fischeri K Schum and Kniphofia foliosa Hochst. The Afro-montane vegetation of the area varies with altitude, and is a key attraction to tourists visiting the area. The GGR is one of the key biodiversity areas in the central highlands of Ethiopia. ${ }^{6,7}$

\section{Data collection}

To collect data on species richness and abundance of wild mammals, birds, and woody plants across the landscape, transects were randomly set with the aid of a GARMIN 75 GPS device and each transect sampling a major existing habitat type within the EHH and in FGH. Accordingly, a total of six transects were aligned, i.e, three transects within the EHH and other three transects within the FGH. Along each transect, the viewable area of each habitat patch was quantified by walking perpendicularly from a given line transect until the unevenness of the topography or the thickness of the vegetation cover no longer allowed viewing that transect. ${ }^{9,10}$ The GPS locations on both sides of all the viewable parts of each habitat type were then taken. This activity was important in determining the sample area of each habitat type along each transect. The GPS locations, which were taken on both sides of the visible points for each transect were transformed into the Ethiopian coordinate system and imported into Arc GIS, and overlaid on the map of the study site. We, then, digitized the GPS coordinates of all the visible points for each transect using lines to make a polygon along all transects. This gave us the areas of all the habitats sampled in each transect. Transects varied in length from 0.5 to $0.8 \mathrm{~km}$ i.e, the length of each transect varied with the size of each habitat patch. We took transect samples whose total area was about 53.18ha.

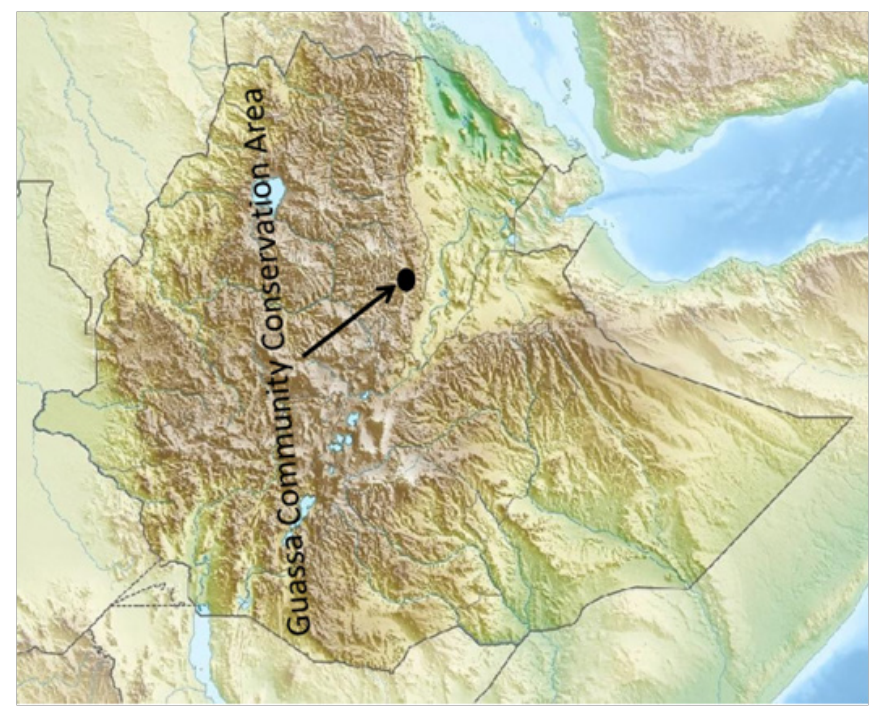

Figure 2 Map showing the location of the GCCA in the central highlands of Ethiopia.

\section{Population census of wild mammals and birds}

To measure the densities of wild mammals along each transect, we conducted regular population censusing by walking along each transect within the EHH and the FGH. During each field census, the observed wild mammal species were identified and recorded along with their sex-age class, group size and occurrence of habitat type. For bird species, a point counting method was applied. Along each transect, with the help of binoculars and field guide, each encountered bird species was identified and its group size was estimated in the two habitats. Since identifying the sex-age class of each observed bird species in the field was difficult, only their numbers were estimated when encountered during the census. The radius of the point counting depended on the visibility of the habitat patch, i.e., more visible habitat patches have longer radius than patches with dense vegetation cover. For both wild mammals and birds, counts were carried out early in the morning from 06:00 to 09:00 and late in the afternoon from 16:00 to 18:30 local time, when wild mammals and birds were most active. To increase the reliability of the field data, each transect was assessed four times. The data were collected from May 2014 to March 2015. 


\section{Estimating species richness and abundance of woody plants}

A systematic sampling design was employed to lay circular plots and collect data on abundance and species richness of woody plants. Following each transect aligned for wild mammal population censusing, the first plot within each habitat patch on each transect was randomly located. Then, successive plots were systematically added at $100 \mathrm{~m}$ intervals along each transect. Accordingly, a total of 39 plots i.e, 18 plots within the EHH and other 21 plots within the FGH were laid down. This suggests that the number of plots laid along each transect depended on the total length of the sample transect. A circular sample plot with a radius of $10 \mathrm{~m}$ was demarcated on each line transect. Within the circular plots, the identity and number of stems of all tree species (woody individuals with a height of $\geq 3 \mathrm{~m}$ ) were determined and recorded. Then, a circular nested plot of $3 \mathrm{~m}$ radius was laid down within the larger circular plot and identity and numbers of stems of all shrubs (woody individuals with a height of $<3 \mathrm{~m}$ and $0.5 \mathrm{~m}$ ) were determined and recorded. Similarly, for seedlings of all tree species (woody individuals with a height of $<0.5 \mathrm{~m}$ ), their identity and number of individuals were determined in circular nested sub-plot of $1 \mathrm{~m}$ radius within the larger circular plot. The data were collected from May 2014 to March 2015.

\section{Data analyses}

\section{Species richness, evenness and diversity}

Species richness is a measure of the number of different species represented in an ecological community, landscape or region. Species richness is simply a count of species, but it does not take into account the abundances of the species or their relative distributions. However, species evenness is a measure of the relative abundance of the different species making up the richness of an area. Thus, species evenness quantifies how equal the abundances of the species are. Evenness compares the similarity of the population size of each of the species present. ${ }^{11}$ A diversity index is a quantitative measure that reflects how many different types (such as species) there are in a dataset, and simultaneously takes into account how evenly the basic entities (such as individuals) are distributed among those types. The value of a diversity index increases both when the number of types (i.e. species richness) increases and when species evenness (i.e. how equal the abundances of the species are) increases. For a given number of types, the value of a diversity index is maximized when all types are equally abundant. Accordingly, Shannon diversity indices ${ }^{11}$ for wild mammals, birds, and woody species recorded in the EHH and FGH were computed. Shannon diversity index is expressed by the formula.

$$
H=-\sum_{i=1}^{S}\left(\mathrm{P}_{i}^{*} \operatorname{In} \mathrm{P}_{i}\right)
$$

Where $\mathrm{H}=$ Shannon diversity index, $\mathrm{P}=$ fraction of the entire population made up of species $\mathrm{i}$ and $\mathrm{S}^{1}=$ numbers of species encountered.

$$
p_{i}=\frac{n_{i}}{N}
$$

Where $n_{i}=$ number of individuals of species " $\mathrm{i}$ ", $\mathrm{N}=$ total number of individuals of all species and $\mathrm{p}_{\mathrm{i}}=$ relative abundance of species " $\mathrm{i}$ ".

Shannon's equitability $\left(J^{\prime}\right)^{11}$ was also computed for wild mammals, birds, and woody species recorded in the EHH and FGH. Shannon's equitability $\left(J^{\prime}\right)$ measures the evenness of a taxon and can be easily calculated by dividing the value of $\mathrm{H}$ with $\mathrm{H}_{\max }$, which equals to $\ln \mathrm{S}$ ( $\mathrm{S}=$ number of species encountered). Its value ranges between 0 and 1 . If abundance is concentrated to one type, and the other types are very rare (even if there are many of them), Shannon equitability approaches zero. When there is only one type in the dataset, Shannon equitability exactly equals zero. The less variation in taxon between the species, the higher $J$ 'is. ${ }^{11}$

$$
J^{\prime}=\frac{H^{\prime}}{H_{\max }^{\prime}}
$$

where $\mathrm{H}^{\prime}$ is the number derived from Shannon diversity index and $\mathrm{H}_{\text {max }}^{\prime}$ is the maximum value of $\mathrm{H}^{\prime}$, equal to

$$
H_{\max }^{\prime}=-\sum_{i=1}^{S} \operatorname{In} n_{S}^{1}=\operatorname{In} S
$$

where $S$ is the total number of species.

\section{Densities}

The sample area information was incorporated with population census data obtained through transect counting of wild mammal species. Then, the numbers of individuals of each wild mammal species counted along each transect during each census was divided by the visible area of the respective transect for each habitat type. That enabled us to estimate the densities of each wild mammal species in each habitat type (Tables 1). As density is one of the objective measures of abundance, this helped us to estimate and compare the abundance of each wild mammal species inside the EHH and the FGH. Densities of each bird species inside the EHH and the FGH were computed by dividing the numbers of individuals of each bird species to the area of the respective point transects where that particular bird species was observed and counted. The results of these analyses were presented in Table 2. Moreover, the inventory data for each woody plant species were divided by the sample area of each circular plot to estimate the densities of each woody species i.e., densities of trees, shrubs, and seedlings in the EHH, and FGH. To make comparisons of the densities of each woody species to be more comprehensive, densities of trees, shrubs, and seedlings of individuals of each woody species were summed for that particular plot and habitat type (Table 2). A two-way ANOVA was used to check whether wild mammals, birds, and woody species exhibit differences in their densities in different habitat types. ${ }^{12}$ To do so, we included habitat type and species as predictors, with densities of wild mammals, birds, and woody species as the dependent variables. For mean comparisons, an independent t-test was used to check if each species of wild mammals, birds, and woody species differs in its respective densities in the EHH and FGH. The overall densities of each taxon (i.e. wild mammals, birds, and woody plant species) in the EHH versus in the FGH were calculated by dividing the total numbers of individuals of each species counted in each habitat by the area of each habitat. As the area was expressed in hectares, thus, the overall densities of each taxon for that particular habitat was expressed in terms of total number of individuals per hectare as shown in Figure 3-5. The alpha value was defined as being 0.05 . All the analyses were undertaken by using SPSS version 16 .

\section{Results}

\section{Species richness, diversity and evenness}

The species richness (Table 3), diversity, and evenness of wild mammals were $11,1.6$, and 0.67 , respectively, in the $\mathrm{EHH}$, and 11 , 
1.4, and 0.6, respectively, in the FGH. Similarly, the species richness (Table 4), diversity, and evenness of birds were 33, 3.3, and 0.96, respectively, in the $\mathrm{EHH}$, and 29, 3, and 0.88, respectively, in the FGH. The woody species were represented by $16,2.7$, and 0.97 species richness (Table 5), diversity, and evenness, respectively, in the $\mathrm{EHH}$, and 16, 2.6, and 0.94 species richness (Table 5), diversity and evenness, respectively, in the FGH.

\section{Densities of wild mammals}

The total mean densities of wild mammals recorded in the EHH and FGH were 16.0 and 7.5 individuals, respectively. The maximum densities of wild mammals varied between about 0.1 individual of honey badger $\mathrm{ha}^{-1}$ in the FGH and 8 individuals of gelada $\mathrm{ha}^{-1}$ in the EHH. The highest (mean $\left.=5.6 \pm 2.1 \mathrm{ha}^{-1}\right)$ and lowest (mean $\left.=0.01 \pm 0.2 \mathrm{ha}^{-1}\right)$ mean densities of wild mammals were recorded in EHH and FGH, respectively. However, the highest percentage of sightings $(91.7 \%)$ of wild mammals per transect was recorded in both habitats. The mean comparisons for the densities of six wild mammal species significantly differed between the two habitats where the mean densities of each wild mammal species were greater in the EHH than in the FGH (Table 1). Overall, densities of wild mammals showed significant difference between the EHH and the FGH ( $\mathrm{F}=58.36$; $\mathrm{df}=1$; $\mathrm{P}<0.001$ ) (Figure 3). Species also significantly affected densities of wild mammals between the $\mathrm{EHH}$ and the $\mathrm{FGH}(\mathrm{F}=88.65 ; \mathrm{df}=10$; $\mathrm{P}<0.001)$. Furthermore, habitat type and species interacted and significantly affected densities of wild mammals between the two habitats $(\mathrm{F}=11.94 ; \mathrm{df}=10 ; \mathrm{P}<0.001)$

Table I Mean densities, standard error of the mean (i.e. SE), maximum densities, number of sightings of the species and sightings per transect walk of wild mammals recorded in the two study habitats

\begin{tabular}{|c|c|c|c|c|c|c|c|c|}
\hline \multirow[t]{2}{*}{$\begin{array}{l}\text { Wild mammal } \\
\text { species }\end{array}$} & \multicolumn{2}{|c|}{$\begin{array}{l}\text { Mean density } \\
\mathrm{Ha}^{-1}\end{array}$} & \multicolumn{2}{|c|}{$\begin{array}{l}\text { Maximum } \\
\text { density } \mathbf{H a}^{-1}\end{array}$} & \multicolumn{2}{|c|}{$\begin{array}{l}\text { Number of sightings } \\
\text { of the species }\end{array}$} & \multicolumn{2}{|c|}{$\begin{array}{l}\text { Sightings per } \\
\text { transect walk (\%) }\end{array}$} \\
\hline & $\mathrm{FGH}( \pm \mathrm{SE})$ & FGH(ISE) & ЕНH & FGH & EHH & FGH & EHH & FGH \\
\hline African civet* & $0.2( \pm 0.10)$ & $0.01( \pm 0.300)$ & 0.3 & 0.1 & 11 & 1 & 91.7 & 8.3 \\
\hline Common mol-rat & $5.3( \pm 2.20)$ & $2.7( \pm 7.40)$ & 7.4 & 3.8 & 11 & 11 & 91.7 & 91.7 \\
\hline Ethiopian highland hare & $0.3( \pm 0.10)$ & $0.1( \pm 0.10)$ & 0.5 & 0.2 & 11 & 10 & 91.7 & 83.3 \\
\hline Ethiopian wolf & $0.4( \pm 0.20)$ & $0.2( \pm 0.10)$ & 0.8 & 0.3 & 10 & 11 & 83.3 & 91.7 \\
\hline Gelada* & $5.6( \pm 2.10)$ & $2.1( \pm 0.80)$ & 7.9 & 3.4 & 11 & 11 & 91.6 & 91.7 \\
\hline Honey badger* & $0.2( \pm 0.10)$ & $0.01( \pm 0.020)$ & 0.3 & 0.1 & 9 & 1 & 75 & 8.3 \\
\hline Golden jackal* & $0.3( \pm 0.10)$ & $0.1( \pm 0.04)$ & 0.3 & 0.1 & 11 & 8 & 91.7 & 66.7 \\
\hline Klipspringer* & $0.4( \pm 0.20)$ & $0.1( \pm 0.10)$ & I & 0.2 & 11 & 3 & 91.7 & 25 \\
\hline Rodent spp & $2.9( \pm 1.40)$ & $2.0( \pm 0.80)$ & 5.5 & 3 & 11 & 11 & 91.7 & 91.7 \\
\hline Serval cat* & $0.2( \pm 0.10)$ & $0.04( \pm 0.040)$ & 0.3 & 0.1 & 11 & 5 & 91.7 & 41.7 \\
\hline Spotted hyena & $0.2( \pm 0.10)$ & $0.1( \pm 0.04)$ & 0.3 & 0.1 & 9 & 9 & 75 & 75 \\
\hline Total & $16.0( \pm 6.70)$ & $7.46( \pm 9.740)$ & & & & & & \\
\hline
\end{tabular}

Table 2 Mean densities, standard error of the mean (i.e. SE), maximum densities, number of sightings of the species and sightings per transect walk of birds recorded in the two study habitats

\begin{tabular}{|c|c|c|c|c|c|c|c|c|}
\hline \multirow[t]{2}{*}{ Bird species } & \multicolumn{2}{|l|}{$\begin{array}{l}\text { Mean } \\
\text { density } \mathrm{Ha}^{-1}\end{array}$} & \multicolumn{2}{|c|}{$\begin{array}{l}\text { Maximum } \\
\text { density } \mathrm{Ha}^{-1}\end{array}$} & \multicolumn{2}{|c|}{$\begin{array}{l}\text { Number of sightings } \\
\text { of the species }\end{array}$} & \multicolumn{2}{|c|}{$\begin{array}{l}\text { Sightings per } \\
\text { transect walk (\%) }\end{array}$} \\
\hline & EHH( $( \pm$ SE $)$ & FGH( \pm SE $)$ & EHH & FGH & EHH & FGH & EHH & FGH \\
\hline Black-winged lovebird* & $29.1( \pm 1.70)$ & $0.0( \pm 0.00)$ & 62.2 & 0.0 & 66.0 & 0.0 & 91.7 & 0.0 \\
\hline Wattled ibis* & $20.0( \pm 1.90)$ & $2.7( \pm 0.60)$ & 62.2 & 22.7 & 54.0 & 43.0 & 75.0 & 51.2 \\
\hline Wattled crane* & $6.4( \pm 1.30)$ & $1.8( \pm 0.40)$ & 39.3 & 17.5 & 20.0 & 15.0 & 27.8 & 17.9 \\
\hline Augur buzzard* & $5.4( \pm 1.20)$ & $1.2( \pm 0.40)$ & 58.9 & 26.2 & 22.0 & 13.0 & 30.6 & 15.5 \\
\hline Cisticola spp* & $28.6( \pm 2.20)$ & $3.4( \pm 0.60)$ & 62.2 & 21.8 & 55.0 & 48.0 & 76.4 & 57.1 \\
\hline White-collard pigeon* & $52.3( \pm 2.80)$ & $20.8( \pm 1.40)$ & 111.9 & 53.0 & 70.0 & 61.0 & 97.2 & 72.6 \\
\hline Speckled pigeon* & $36.8( \pm 3.30)$ & $2.5( \pm 0.60)$ & 99.5 & 26.2 & 56.0 & 18.0 & 77.8 & 21.4 \\
\hline Pied crow* & $27.4( \pm 2.10)$ & $3.3( \pm 0.70)$ & 66.1 & 21.8 & 57.0 & 22.0 & 79.2 & 26.2 \\
\hline Thick-billed raven* & $21.0( \pm 2.50)$ & $2.4( \pm 2.20)$ & 74.6 & 24.4 & 49.0 & 19.0 & 68.1 & 22.6 \\
\hline Fan-tailed raven* & $22.7( \pm 0.50)$ & $3.2( \pm 2.20)$ & 62.2 & 21.8 & 49.0 & 23.0 & 68.1 & 27.4 \\
\hline Blue-winged goose* & $18.8( \pm 0.60)$ & $3.3( \pm 2.00)$ & 74.6 & 17.5 & 46.0 & 25.0 & 63.9 & 29.8 \\
\hline
\end{tabular}


Table Continued....

\begin{tabular}{|c|c|c|c|c|c|c|c|c|}
\hline \multirow[t]{2}{*}{ Bird species } & \multicolumn{2}{|l|}{$\begin{array}{l}\text { Mean } \\
\text { density } \mathrm{Ha}^{-1}\end{array}$} & \multicolumn{2}{|c|}{$\begin{array}{l}\text { Maximum } \\
\text { density } \mathrm{Ha}^{-1}\end{array}$} & \multicolumn{2}{|c|}{$\begin{array}{l}\text { Number of sightings } \\
\text { of the species }\end{array}$} & \multicolumn{2}{|c|}{$\begin{array}{l}\text { Sightings per } \\
\text { transect walk (\%) }\end{array}$} \\
\hline & EHH( \pm SE) & FGH( \pm SE) & EHH & FGH & EHH & FGH & EHH & FGH \\
\hline Grey kestrel* & $3.7( \pm 1.10)$ & $0.9( \pm 1.50)$ & 24.9 & 8.7 & 18.0 & 13.0 & 25 & 15.5 \\
\hline Yellow-necked spurfowl* & $8.0( \pm 1.10)$ & $2.0( \pm 0.40)$ & 37.3 & 9.4 & 28.0 & 21.0 & 38.9 & 25.0 \\
\hline White-backed vulture $* *$ & $10.8( \pm 1.30)$ & $\mathrm{I} .6( \pm 0.40)$ & 37.3 & 13.1 & 38.0 & 14.0 & 52.8 & 16.7 \\
\hline Hadada ibis* & $17.9( \pm 2.10)$ & $2.9( \pm 0.60)$ & 74.6 & 21.2 & 45.0 & 22.0 & 62.5 & 26.2 \\
\hline Ethiopian swallow* & II.7( $( \pm 1.60)$ & $2.8( \pm 0.50)$ & 49.8 & 18.8 & 35.0 & 25.0 & 48.6 & 29.8 \\
\hline Blue-eared glossy starling* & $38.8( \pm 3.30)$ & $15.9( \pm 1.30)$ & 111.9 & 48.7 & 59.0 & 69.0 & 81.9 & 82.1 \\
\hline Abyssinian long claw* & $8.3( \pm 1.40)$ & $\mathrm{I} .7( \pm 0.40)$ & 66.1 & 24.4 & 29.0 & 16.0 & 40.3 & 10.1 \\
\hline Hooded vulture* & 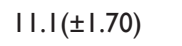 & $2.7( \pm 0.60)$ & 49.8 & 18.8 & 31.0 & 20.0 & 43.1 & 23.8 \\
\hline Sunbird spp* & $22.7( \pm 2.10)$ & $0.0( \pm 0.00)$ & 62.2 & 0 & 53.0 & 0.0 & 73.6 & 0.0 \\
\hline Helmeted guineafowl* & $47.5( \pm 3.20)$ & $15.5( \pm 1.30)$ & 99.5 & 60.9 & 65.0 & 67.0 & 90.3 & 79.8 \\
\hline Abyssinian catbird* & $22.9( \pm 1.70)$ & $0.0( \pm 0.00)$ & 49.8 & 0 & 58.0 & 0.0 & 80.6 & 0.0 \\
\hline Black-headed weaver* & $36.0( \pm 3.20)$ & $7.4( \pm 1.00)$ & 99.2 & 39.3 & 55.0 & 41.0 & 76.4 & 48.8 \\
\hline Yellow-vented bulbul* & II.4(土I.50) & $3.6( \pm 0.60)$ & 71.7 & 42.4 & 39.0 & 34.0 & 54.2 & 40.5 \\
\hline Rouget's rail* & $7.4( \pm 1.00)$ & $2.3( \pm 0.30)$ & 37.3 & 10.6 & 37.0 & 34.0 & 51.4 & 40.5 \\
\hline White-rumped seed eater* & $19.3( \pm 2.30)$ & $6.3( \pm 0.80)$ & 55.1 & 23.6 & $4 I .0$ & 39.0 & 56.9 & 46.4 \\
\hline Ankober serin* & $12.6( \pm 1.20)$ & $0.0( \pm 0.00)$ & 33.1 & 0 & 51.0 & 0.0 & 70.8 & 0.0 \\
\hline Sacred ibis* & $17.8( \pm 2.20)$ & $5.2( \pm 0.80)$ & 62.2 & 22.7 & 41.0 & 35.0 & 56.9 & 41.7 \\
\hline Spot-breasted lapwing* & II.3( 1.1 .40$)$ & $4 . I( \pm 0.50)$ & 39.3 & 16.3 & 38.0 & 40.0 & 52.8 & 47.6 \\
\hline Total & $668.5( \pm 58.90)$ & $158.3( \pm 26.20)$ & & & & & & \\
\hline
\end{tabular}

Table 3 List of species of wild mammals recorded during the study periods. All the II wild mammal species were seen in both study habitats (i.e., EHH and $\mathrm{FGH}$ )

\begin{tabular}{lll}
\hline Family names & Scientific names & Common names \\
\hline Viverridae & Civettictis civetta & African civet \\
Bathyergidae & Cryptomys hottentotus & Common mol-rat \\
Leporidae & Lepus starcki & Ethiopian highland hare \\
Canidae & Canis simensis & Ethiopian wolf \\
Cercopithecidae & Theropithecus gelada & Gelada \\
Mustelidae & Mellivora capensis & Honey badger \\
Canidae & Canis aureus & Golden jackal \\
Bovidae & Oreotragus oreotragus & Klipspringer \\
Muridae & Rodent spp & Rodent spp \\
Felidae & Leptailurus serval & Serval cat \\
Hyaenidae & Crocuta crocuta & Spotted hyena \\
\hline
\end{tabular}

\section{Densities of birds}

The total mean densities of birds recorded in the EHH and FGH were 668.5 and 158.3 individuals, respectively. The maximum densities of birds varied between no individuals in the FGH (blackwinged lovebird, sunbird spp, abyssinian catbird and Ankober serin) and about 112 individuals ha ${ }^{-1}$ (white-collard pigeon and blue-eared glossy starling) in the EHH. The highest (mean $=52.3 \pm 2.8 \mathrm{ha}^{-1}$, whitecollared pigeon) and lowest (no individual, black-winged lovebird, sunbird spp, abyssinian catbird and Ankober serin) mean densities of birds were recorded in $\mathrm{EHH}$ and $\mathrm{FGH}$, respectively. However, the highest percentage of sightings (97.2\%) of birds per transect was recorded in the EHH. The mean comparisons for the densities of the 33 bird species significantly differed between the two habitats where the mean densities of each bird species were greater in the EHH than in the FGH (Table 5). Overall, densities of birds showed significant difference between the EHH and the FGH $(\mathrm{F}=1.93$; $\mathrm{df}=1 ; \mathrm{P}<0.001)$ (Figure 4). Species also significantly affected densities of birds between the EHH and FGH $(\mathrm{F}=71.43 ; \mathrm{df}=32 ; \mathrm{P}<0.001)$. Furthermore, habitat type and species interacted and significantly affected densities of birds between the two habitats $(\mathrm{F}=20.58 ; \mathrm{df}=32 ; \mathrm{P}<0.001)$. 
Table 4 Mean densities, standard error of the mean (i.e. SE), maximum densities, number of sightings of the species and sightings per transect walk of wild mammals recorded in the two study habitats

\begin{tabular}{|c|c|c|}
\hline Family names & Scientific names & Common names \\
\hline Psittaculidae & Agapornis taranta & Black-winged lovebird \\
\hline Threskiornithidae & Bostrychia carunculata & Wattled ibis \\
\hline Gruidae & Bugeranus carunculatus & Wattled crane \\
\hline Accipitridae & Buteo rufofuscus & Augur buzzard \\
\hline Cisticolidae & Cisticola spp & Cisticola spp \\
\hline Columbidae & Columba albitorques & White-collard pigeon \\
\hline Columbidae & Columba gunea & Speckled pigeon \\
\hline Corvidae & Corvus albus & Pied crow \\
\hline Corvidae & Corvus crassirostris & Thick-billed raven \\
\hline Corvidae & Corvus rhipidurus & Fan-tailed raven \\
\hline Anatidae & Cyanochen cyanoptera & Blue-winged goose \\
\hline Ardeidae & Egretta garzetta & Little egret \\
\hline Falconidae & Falco ardosiaceus & Grey kestrel \\
\hline Phasianidae & Francolinus leucoscepus & Yellow-necked spurfowl \\
\hline Accipitridae & Gyps bengalensis & White-backed vulture \\
\hline Threskiornithidae & Hagedasha hegedash & Hadada ibis \\
\hline Hirundinidae & Hirundo aethiopica & Ethiopian swallow \\
\hline Sturnidae & Lamprotornis chalybaeus & Blue-eared glossy starling \\
\hline Motacillidae & Macronyx flavicollis & Abyssinian long claw \\
\hline Accipitridae & Milvus migrans & Black kite \\
\hline Accipitridae & Necrosyrtes monachus & Hooded vulture \\
\hline Nectariniidae & Nectarinia spp & Sunbird spp \\
\hline Numididae & Numida meleagris & Helmeted guineafowl \\
\hline Timaliidae & Parophasma galinieri & Abyssinian catbird \\
\hline Ploceidae & Ploceus cucullatus & Black-headed weaver \\
\hline Pycnonotidae & Pycnonotus barbatus & Yellow-vented bulbul \\
\hline Rallidae & Rougetius rougetii & Rouget's rail \\
\hline Fringillidae & Serinus albitorques & White-rumped seed eater \\
\hline Fringillidae & Serinus ankoberensis & Ankober serin \\
\hline Fringillidae & Serinus nigriceps & Ethiopian siskin \\
\hline Columbidae & Streptopelia lugens & Dusky turtle dove \\
\hline Threskiornithidae & Threskiornis aethiopicus & Sacred ibis \\
\hline Charadriidae & Vanellus melanocephallus & Spot-breasted lapwing \\
\hline
\end{tabular}

Table 5 List of woody plant species recorded during the study periods.All the 16 woody plant species were found in both study habitats

\begin{tabular}{|c|c|c|}
\hline Family names & Scientific names & Growth form \\
\hline Rosaceae & Alchemilla abyssinica & Shrub \& seedling \\
\hline Rosaceae & Alchemilla rothii & Shrub \& seedling \\
\hline Rosaceae & Alchemilla cyclophylla & Shrub \& seedling \\
\hline Asteraceae & Artemisia afra & Shrub \& seedling \\
\hline Asteraceae & Carduus nyassanus & Shrub \& seedling \\
\hline Cyperaceae & Carex fischeri & Shrub \& seedling \\
\hline Cyperaceae & Carex monostachya & Shrub \& seedling \\
\hline Ericaceae & Erica arborea & Trees, shrub \& seedling \\
\hline Asteraceae & Euryops pinifolius & Shrub \& seedling \\
\hline Asteraceae & Helichrysum citrispinum & Shrub \& seedling \\
\hline Asteraceae & Helichrysum cyosum & Shrub \& seedling \\
\hline Asteraceae & Helichrysum gofense & Shrub \& seedling \\
\hline Asteraceae & Helichrysum splendidum & Shrub \& seedling \\
\hline Hypericaceae & Hypericum revolutum & Trees, shrub \& seedling \\
\hline Asphodelaceae & Kniphofia foliosa & Shrub \& seedling \\
\hline Lobeliaceae & Lobelia rhynchopetalum & Trees, shrub \& seedling \\
\hline
\end{tabular}

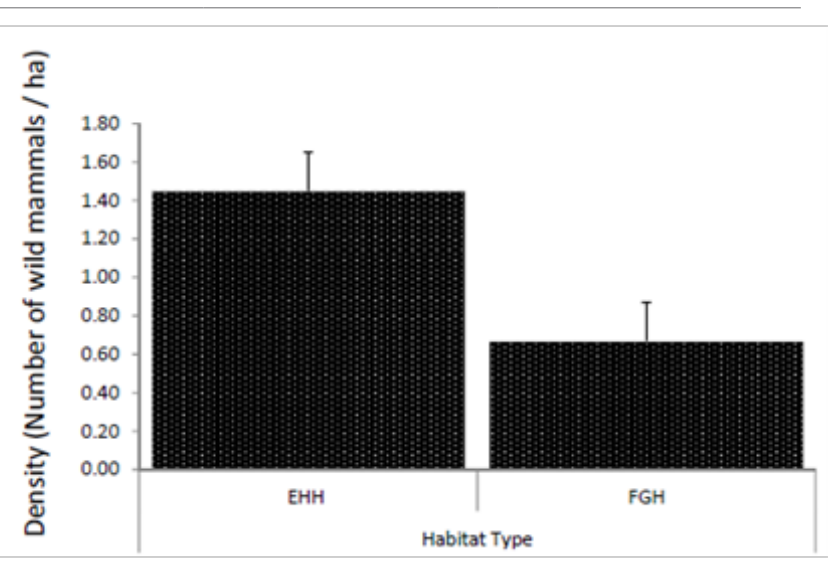

Figure 3 Densities of wild mammals in the two study habitats. The number of individuals of all wild mammals for that particular habitat type is pooled together. The error bars represent +I SE. + I SE is to mean that it is plus I standard error on the mean value. The range of the densities of wild mammals in the $\mathrm{EHH}$ was 7.9 individuals per hectare while it was 3.8 individuals per hectare in the $\mathrm{FGH}$.

\section{Densities of woody species}

The total mean densities of woody species recorded in the EHH and FGH were 37,665.2 and 16,845.6 individuals, respectively. The maximum densities of woody species varied between about 3,185 individuals ha ${ }^{-1}$ in the FGH (about 6 species) and 16,631.3 individuals $\mathrm{ha}^{-1}$ of Erica arborea L in the EHH (Table 6). Moreover, the minimum densities of woody species varied between no individuals in the FGH (about 15 species) and about 6,723 individuals of E. arborea $\mathrm{ha}^{-1}$ in the EHH. The highest (mean $=9,355 \pm 627 \mathrm{ha}^{-1}, E$ arborea) and lowest (mean $=267 \pm 197 \mathrm{ha}^{-1}$, Lobelia rhynchopetalum Hochst ex A Rich.) mean densities of woody species were recorded in EHH and 
FGH, respectively. The highest percentage of sightings $(100 \%)$ of woody species per transect was recorded in the EHH (E arborea, Helichrysum splendidum Thunb and Kniphofia foliosa Hochst). The mean comparisons for the densities of 11 woody species significantly differed between the two habitats where the mean densities of 10 woody species were significantly greater in the EHH than in the FGH. However, the mean density of Alchemilla rothii Oliv was significantly greater in the FGH than in the EHH (Table 6). Overall, densities of woody species showed significant difference between the $\mathrm{EHH}$ and $\mathrm{FGH}(\mathrm{F}=43.38 ; \mathrm{df}=1 ; \mathrm{P}<0.001)$ (Figure 5). The species also significantly affected densities of woody species between the EHH and the FGH $(\mathrm{F}=21.92 ; \mathrm{df}=15 ; \mathrm{P}<0.001)$. Furthermore, habitat type and species interacted and significantly affected densities of woody species between the two habitats $(\mathrm{F}=12.62 ; \mathrm{df}=15 ; \mathrm{P}<0.001)$.

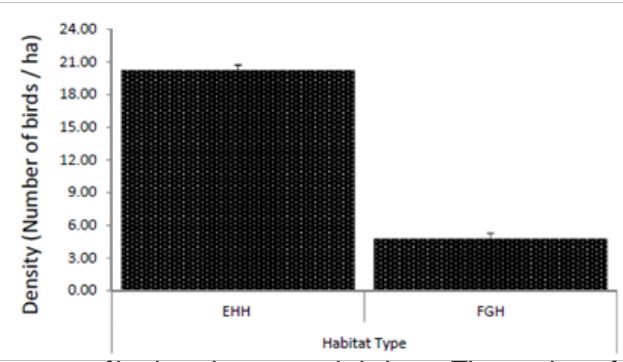

Figure 4 Densities of birds in the two study habitats. The number of individuals of each bird species for that particular habitat type is pooled together. The error bars represent $+\mid$ SE. + I SE is to mean that it is plus I standard error on the mean value. The range of the densities of birds in the EHH was III.9 individuals per hectare while it was 60.9 individuals per hectare in the FGH.

Table 6 Mean densities, standard error of the mean (i.e. SE), maximum densities, number of sightings of the species and sightings per transect walk of woody plants recorded in the two study habitats

\begin{tabular}{|c|c|c|c|c|c|c|c|c|}
\hline \multirow[t]{2}{*}{ Bird species } & \multicolumn{2}{|c|}{$\begin{array}{l}\text { Mean density } \\
\mathrm{ha}^{-1}\end{array}$} & \multicolumn{2}{|c|}{$\begin{array}{l}\text { Maximum } \\
\text { density ha-1 }\end{array}$} & \multicolumn{2}{|c|}{$\begin{array}{l}\text { Number of sightings } \\
\text { of the species }\end{array}$} & \multicolumn{2}{|c|}{$\begin{array}{l}\text { Sightings per } \\
\text { transect walk (\%) }\end{array}$} \\
\hline & EHH( $( \pm S E)$ & FGH( $( \pm S E)$ & EHH & FGH & EHH & FGH & ЕНH & FGH \\
\hline Black-winged lovebird* & $29.1( \pm 1.70)$ & $0.0( \pm 0.00)$ & 62.2 & 0.0 & 66.0 & 0.0 & 91.7 & 0.0 \\
\hline Wattled ibis* & $20.0( \pm 1.90)$ & $2.7( \pm 0.60)$ & 62.2 & 22.7 & 54.0 & 43.0 & 75.0 & 51.2 \\
\hline Wattled crane* & $6.4( \pm 1.30)$ & I.8( \pm 0.40$)$ & 39.3 & 17.5 & 20.0 & 15.0 & 27.8 & 17.9 \\
\hline Augur buzzard* & $5.4( \pm I .20)$ & I.2( \pm 0.40$)$ & 58.9 & 26.2 & 22.0 & 13.0 & 30.6 & 15.5 \\
\hline Cisticola spp* & $28.6( \pm 2.20)$ & $3.4( \pm 0.60)$ & 62.2 & 21.8 & 55.0 & 48.0 & 76.4 & 57.1 \\
\hline White-collard pigeon* & $52.3( \pm 2.80)$ & $20.8( \pm 1.40)$ & 111.9 & 53 & 70.0 & 61.0 & 97.2 & 72.6 \\
\hline Speckled pigeon* & $36.8( \pm 3.30)$ & $2.5( \pm 0.60)$ & 99.5 & 26.2 & 56.0 & 18.0 & 77.8 & 21.4 \\
\hline Pied crow* & $27.4( \pm 2.10)$ & $3.3( \pm 0.70)$ & 66.1 & 21.8 & 57.0 & 22.0 & 79.2 & 26.2 \\
\hline Thick-billed raven* & $21.0( \pm 2.50)$ & $2.4( \pm 2.20)$ & 74.6 & 24.4 & 49.0 & 19.0 & 68.1 & 22.6 \\
\hline Fan-tailed raven* & $22.7( \pm 0.50)$ & $3.2( \pm 2.20)$ & 62.2 & 21.8 & 49.0 & 23.0 & 68.1 & 27.4 \\
\hline Blue-winged goose* & $18.8( \pm 0.60)$ & $3.3( \pm 2.00)$ & 74.6 & 17.5 & 46.0 & 25.0 & 63.9 & 29.8 \\
\hline Little egret* & $36.2( \pm 0.60)$ & $25.3( \pm 2.40)$ & 88.5 & 42.4 & 68.0 & 69.0 & 94.4 & 82.1 \\
\hline Grey kestrel* & $3.7( \pm I .10)$ & $0.9( \pm 1.50)$ & 24.9 & 8.7 & 18.0 & 13.0 & 25.0 & 15.5 \\
\hline $\begin{array}{l}\text { Yellow-necked spurfowl* } \\
\text { White-backed vulture * }\end{array}$ & $8.0( \pm I .10)$ & $2.0( \pm 0.40)$ & 37.3 & 9.4 & 28.0 & 21.0 & 38.9 & 25.0 \\
\hline White-backed vulture $* *$ & $10.8( \pm 1.30)$ & $1.6( \pm 0.40)$ & 37.3 & 13.1 & 38.0 & 14.0 & 52.8 & 16.7 \\
\hline Hadada ibis* & $17.9( \pm 2.10)$ & $2.9( \pm 0.60)$ & 74.6 & 21.2 & 45.0 & 22.0 & 62.5 & 26.2 \\
\hline Ethiopian swallow* & II.7( \pm 1.60$)$ & $2.8( \pm 0.50)$ & 49.8 & 18.8 & 35.0 & 25.0 & 48.6 & 29.8 \\
\hline Blue-eared glossy starling* & $38.8( \pm 3.30)$ & $15.9( \pm 1.30)$ & 111.9 & 48.7 & 59.0 & 69.0 & 81.9 & 82.1 \\
\hline Abyssinian long claw* & $8.3( \pm I .40)$ & I.7( \pm 0.40$)$ & 66.1 & 24.4 & 29.0 & 16.0 & 40.3 & 10.1 \\
\hline Black kite* & II.3( \pm 1.50$)$ & $2.3( \pm 0.40)$ & 49.8 & 16.3 & 38.0 & 22.0 & 52.8 & 26.2 \\
\hline Hooded vulture* & $\mathrm{II} . \mathrm{I}( \pm \mathrm{I} .70)$ & $2.7( \pm 0.60)$ & 49.8 & 18.8 & 31.0 & 20.0 & 43.1 & 23.8 \\
\hline Sunbird spp* & $22.7( \pm 2.10)$ & $0.0( \pm 0.00)$ & 62.2 & 0.0 & 53.0 & 0.0 & 73.6 & 0.0 \\
\hline Helmeted guineafowl* & $47.5( \pm 3.20)$ & $15.5( \pm I .30)$ & 99.5 & 60.9 & 65.0 & 67.0 & 90.3 & 79.8 \\
\hline Abyssinian catbird* & $22.9( \pm 1.70)$ & $0.0( \pm 0.00)$ & 49.8 & 0.0 & 58.0 & 0.0 & 80.6 & 0.0 \\
\hline Black-headed weaver* & $36.0( \pm 3.20)$ & $7.4( \pm 1.00)$ & 99.2 & 39.3 & 55.0 & 41.0 & 76.4 & 48.8 \\
\hline Yellow-vented bulbul* & II.4(土I.50) & $3.6( \pm 0.60)$ & 71.7 & 42.4 & 39.0 & 34.0 & 54.2 & 40.5 \\
\hline Rouget's rail* & $7.4( \pm 1.00)$ & $2.3( \pm 0.30)$ & 37.3 & 10.6 & 37.0 & 34.0 & 51.4 & 40.5 \\
\hline
\end{tabular}


Table Continued...

\begin{tabular}{|c|c|c|c|c|c|c|c|c|}
\hline \multirow[t]{2}{*}{ Bird species } & \multicolumn{2}{|l|}{$\begin{array}{l}\text { Mean density } \\
\mathrm{ha}^{-1}\end{array}$} & \multicolumn{2}{|c|}{$\begin{array}{l}\text { Maximum } \\
\text { density ha }\end{array}$} & \multicolumn{2}{|c|}{$\begin{array}{l}\text { Number of sightings } \\
\text { of the species }\end{array}$} & \multicolumn{2}{|c|}{$\begin{array}{l}\text { Sightings per } \\
\text { transect walk (\%) }\end{array}$} \\
\hline & $\mathrm{EHH}( \pm \mathrm{SE})$ & FGH(ISE) & EHH & FGH & ЕHН & FGH & EHH & FGH \\
\hline White-rumped seed eater* & $19.3( \pm 2.30)$ & $6.3( \pm 0.80)$ & 55.1 & 23.6 & 41.0 & 39.0 & 56.9 & 46.4 \\
\hline Ankober serin* & $12.6( \pm 1.20)$ & $0.0( \pm 0.00)$ & 33.1 & 0.0 & 51.0 & 0.0 & 70.8 & 0.0 \\
\hline Ethiopian siskin* & $19.9( \pm 2.10)$ & $6.9( \pm 0.80)$ & 58.9 & 26.2 & 46.0 & 46.0 & 63.9 & 54.8 \\
\hline Dusky turtle dove* & $13.4( \pm 1.20)$ & $4.3( \pm 0.50)$ & 44.1 & 16.3 & 47.0 & 44.0 & 65.3 & 52.4 \\
\hline Sacred ibis* & $17.8( \pm 2.20)$ & $5.2( \pm 0.80)$ & 62.2 & 22.7 & 41.0 & 35.0 & 56.9 & 41.7 \\
\hline Spot-breasted lapwing* & $11.3( \pm 1.40)$ & 4. $I( \pm 0.50)$ & 39.3 & 16.3 & 38.0 & 40.0 & 52.8 & 47.6 \\
\hline Total & $668.5( \pm 58.90)$ & $158.3( \pm 26.20)$ & & & & & & \\
\hline
\end{tabular}

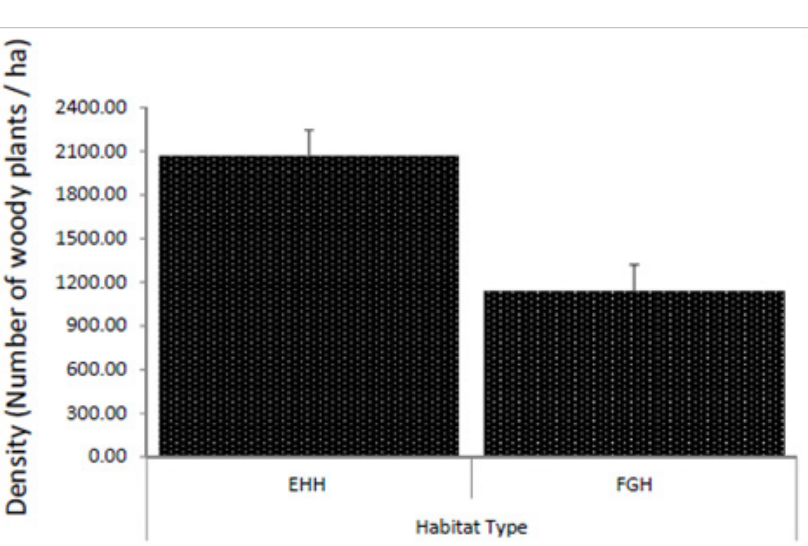

Figure 5 Densities of woody species in the two study habitats. The number of individuals of each woody species for that particular habitat type is pooled together. The error bars represent +I SE. +I SE is to mean that it is plus I standard error on the mean value. The range of the densities of woody plants in the EHH was $16,631.3$ individuals per hectare while it was 6,755.I individuals per hectare in the $\mathrm{FGH}$.

\section{Discussion}

\section{Species diversities of wild mammals, birds and woody species}

As hypothesized, Shannon diversity index revealed that species diversity of wild mammals, birds, and woody species in the EHH were relatively greater than in the FGH. Moreover, as compared to the FGH, Shannon's equitabilities also suggested that wild mammal bird and woody plant communities in the $\mathrm{EHH}$ are of higher species evenness. There are a number of studies that suggested higher species diversity, i.e, species richness and evenness, in areas that relatively receive better conservation from human and livestock induced encroachments. ${ }^{13-15}$ Moreover, compared with open areas, there are a number of studies that documented higher species diversity of wild mammals, birds, and woody species inside area exclosures and protected areas. ${ }^{16-19}$ Unlike wild mammals and woody species richness, the species richness of birds was higher in the EHH than in the FGH. Some of the possible reasons for unequal distribution of the bird species in the two adjacent habitats could be attributed by the difference in habitat resource gradient and densities ${ }^{9,10,20}$ and the presence of human- and livestock-induced disturbances. ${ }^{3,4,21,22}$ In addition, the behavior of some bird species (e.g. shyness to humanand livestock-induced disturbances and attack by predators) may also prevent long distance movements and dispersal, ${ }^{3,23-25}$ which, in turn, determines the number of bird species found in a particular community.

\section{Densities of wild mammals, birds and woody species}

As hypothesized, the study revealed that the overall densities of wild mammals, birds, and woody species in the EHH were all significantly higher than in the FGH. One of the possible explanations is that when natural vegetation existing in the GCEL is reasonably protected from illegal human- and livestock-induced encroachments, they will attract plenty of wild mammal and bird species from the adjacent open fields. This is because they provide the incoming wild mammals and birds with quality food, ${ }^{1,2}$ suitable cover from environmental extremes, ${ }^{3}$ breeding sites ${ }^{4}$ and concealment from risk of predation. ${ }^{5}$ It was also noted that natural vegetation inside exclosures and restoration sites is sanctuaries for several wild mammal and bird species that have almost disappeared in most parts of encroached and degraded areas. ${ }^{26}$ Similarly, in other parts of Africa where human-induced disturbance is low, it has been shown that the abundance of animals increases. ${ }^{27,28}$ In addition, several endemic and endangered wild mammal and bird species have been documented inside exclosed areas such as sacred groves ${ }^{29}$ and protected areas that are relatively free from human- and livestock-induced disturbances. ${ }^{30}$ For example, sacred groves, which form in situ conservation sites and act as a refuge for several wild mammal and bird species, are becoming ecologically important. ${ }^{26}$ The role played by exclosures and protected areas, including eco-lodges, in enhancing woody species regeneration that will emerge from the soil seed banks have also been well documented. ${ }^{13-18,31,32}$ Moreover, the exclosures can buffer against the depletion of genetically adapted local variants and overall biodiversity in a given region. They can also serve as important recruitment areas to surrounding ecosystems. ${ }^{26}$ It was also noted that the EHH in the GCCA supports rare and endemic plant species, including giant lobelia, species of Alchemilla, Helichrysum, Carex and Artemisia afra Jacq. ex Willd and other moorland vegetation.?

\section{Conclusion}

The study examined the contribution of the GCEL in the conservation of wild mammals, birds, and woody species. In line with our predictions, the results revealed that densities and species diversity of wild mammals, birds, and woody plants in the EHH were all relatively greater than in the FGH. Other than academic purpose, we believe that the findings of this study generated quantitative scientific information for policy-makers and planners that can be instrumental toward better and more informed decision-making for eco-lodge establishment and management that is geared toward local 
biodiversity conservation. The biodiversity data on the diversities and densities of wild mammals, birds, and woody species in the EHH and FGH were collected in a single year. This suggests that the data do not capture possible changes over time in abundance, species richness and evenness of wild mammals, birds, and woody species in the EHH and FGH. Thus, future research can add a time dimension as another factor to investigate if densities and diversity of wild mammals, birds, and woody species in the two study habitats change over time.

\section{Acknowledgements}

Authors thank the Research and Community Service Office at Debre Berhan University for supporting this research financially. We are very grateful to the following institutions: GCCA, Culture and Tourism Office of Menz-Gera Midir District, and Menz-Gera Midir District Administration Office for their unreserved co-operation in giving the permit to work on the GCEL and the CCCA. The enumerators who helped in handling the field data collection are gratefully acknowledged.

\section{Conflicts of interest}

Authors declare that there are no conflicts of interest.

\section{References}

1. Gross JE, Alkon PU, Demment MW. Grouping patterns and spatial segregation by Nubian Ibex. Journal of Arid Environments. 1995;30:423439 .

2. Stephens DW, Krebs JR. Foraging Theory. USA: Princeton University Press; 1986.

3. Evangelista P, Swartzinski P, Waltermire R. A profile of the mountain nyala (Tragelaphus buxtoni). African Indaba. 2007;5:1-48.

4. Morris DW, Kotler BP, Brown JS, et al. Behavioral indicators for conserving mammal diversity. Ann N Y Acad Sci. 2009;1162:334-356.

5. Kotler BP, Gross JE, Mitchell WA. Applying patch use to assess aspects of foraging behavior in Nubian Ibex. The Journal of Wildlife Management. 1994;58:299-307.

6. Ashenafi ZT, Leader Williams N. The Resilient Nature of Common Property Resource Management Systems: a case study from the Guassa area of Menz, Ethiopia. Ethiopia: Addis Ababa; 2006.

7. Ashenafi ZT, Leader Williams N. Indigenous common property resource management in the central highlands of Ethiopia. Human Ecology. 2005;33(4):539-563.

8. Ashenafi ZT, Coulson T, Sillero Zubiri C, et al. Behavior and ecology of the Ethiopian wolf in a human-dominated landscape outside protected areas. Animal Conservation. 2005;8:113-121.

9. Druce DJ. Species requirements, coexistence and habitat partitioning at the community level: rock hyrax and klipspringer. South Africa: University of KwaZulu-Natal; 2005. 122 p.

10. Tadesse SA, Kotler BP. Habitat choices of nubian ibex (Capra nubiana) evaluated with a habitat suitability modeling and isodar analysis. Israel Journal of Ecology \& Evolution. 2010;56:55-74.

11. Magurran AE. Measuring biological diversity. Journal of Vegetation Science. 2004:854-856.

12. Snedecor GW, Cochran WG. Statistical methods. 8th ed. USA: Iowa State University Press; 1989.

13. Bahiru KM. Enclosure as a viable option for rehabilitation of degraded lands and biodiversity conservation: the case of kallu woreda, Southern wello. Ethiopia: Addis ababa university school of graduate studies; 2008. p. 1-99.
14. Kasim M, Asfaw Z, Derero A, et al. The role of area closure on the recovery of woody species composition on degraded lands and its socioeconomic importance in Central Rift Valley Area, Ethiopia. International Journal of Development Research. 2015;5(2):3348-3358.

15. Shono K, Cadaweng EA, Durst PB. Application of assisted natural regeneration to restore degraded tropical forestlands. Journal of Restoration Ecology. 2007;15(4):620-626.

16. Emiru B, Demel T, Barklund P. Actual and potential contribution of exclosures to enhance biodiversity of woody species in the drylands of Eastern Tigray. Journal of the Drylands. 2006;1:134-147.

17. Mengistu T, Teketay D, Kulten J, et al. The Role of Communities in Closed Area Management in Ethiopia. Mountain Research and Development. 2005;25(1):44-50.

18. Wassie A, Teketay D, Powell N. Church forests in North Gondar Administrative Zone, Northern Ethiopia. Forests, Trees \& Livelihood. 2004;15(4):349-374.

19. Wassie A, Sterck FJ, Bongers F. Species and structural diversity of church forests in a fragmented Ethiopian highland landscape. Journal of Vegetation Science. 2010;21:938-948.

20. Atickem A, Loe LE, Langangen O, et al. Estimating population size and habitat suitability for mountain nyala in areas with different protection status. AGRIS. 2011;14:409-418.

21. Kebede AT. Sustaining the Allideghi Grassland of Ethiopia: Influence of pastoralism and vegetation change. USA: Utah State University; 2009. $309 \mathrm{p}$.

22. Tadesse SA, Kotler BP. The impacts of humans and livestock encroachments on the habitats of mountain nyala (Tragelaphus buxtoni) in Munessa, Ethiopia. International Journal of Biodiversity \& Conservation. 2013;5(9):572-583.

23. Morris DW. How can we apply theories of habitat selection to wildlife conservation and management. European Journal of Wildlife Research. 2003;30:303-319.

24. Morris DW. Ecological scale and habitat use. Ecology. 1987;68(2):362369.

25. Morris DW. Habitat dependent population regulation and community structure. Evolutionary Ecology. 1988;2:253-269.

26. Wassie A. The contribution of ethiopian orthodox tewahido church in forest management and its best practices to be scaled up in north shewa zone of amhara region, Ethiopia. Sweden: Agriculture, Forestry and Fisheries; 2002. p. 123-137.

27. Monadjem A. Habitat preference and biomass of small mammals in Swaziland. African Journal of Ecology. 1997;35:64-72.

28. Monadjem A. Geographic distribution patterns of small mammals in Swaziland in relation to abiotic factors and human land-use activity. Biodiversity Conservation. 1999;8(2):223-237.

29. Gadgil M, Vartak VD. The sacred groves of western Ghats in India. Economic Botany. 1976;30:152-160.

30. Hillman JC. Compendium of wildlife conservation information. Ethiopia: NYZS and EWCO, Addis Ababa; 1993. 580 p.

31. Girma A, Huss KA, Tennigkeit J. Forest regeneration without planting: The case of community managed forest in the Bale Mountains of Ethiopia. Journal of the Drylands. 2006;1(1):26-34.

32. Mekuria A, Teketay D, Olsson M. Soil seed flora, germination and regeneration pattern of woody species in an acacia woodland of Rift Valley in Ethiopia. Journal of Arid Environments. 1999;43(4):411-435. 